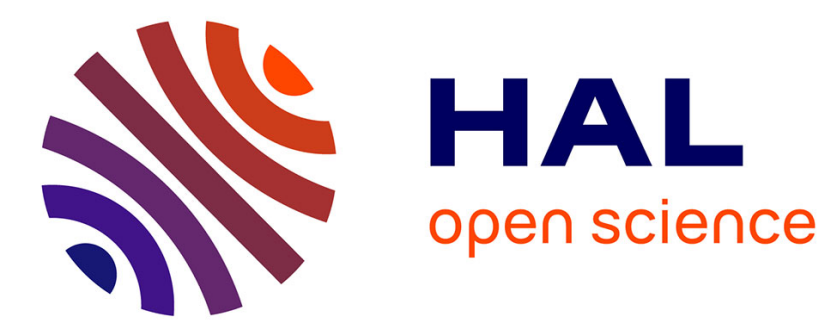

\title{
Status of the glass sponge reefs in the Georgia Basin
}

Sarah E. Cook, Kim W. Conway, Brenda Burd

\section{To cite this version:}

Sarah E. Cook, Kim W. Conway, Brenda Burd. Status of the glass sponge reefs in the Georgia Basin. Marine Environmental Research, 2008, 66, 10.1016/j.marenvres.2008.09.002 . hal-00563054

\section{HAL Id: hal-00563054 https://hal.science/hal-00563054}

Submitted on 4 Feb 2011

HAL is a multi-disciplinary open access archive for the deposit and dissemination of scientific research documents, whether they are published or not. The documents may come from teaching and research institutions in France or abroad, or from public or private research centers.
L'archive ouverte pluridisciplinaire HAL, est destinée au dépôt et à la diffusion de documents scientifiques de niveau recherche, publiés ou non, émanant des établissements d'enseignement et de recherche français ou étrangers, des laboratoires publics ou privés. 


\section{Accepted Manuscript}

Status of the glass sponge reefs in the Georgia Basin

Sarah E. Cook, Kim W. Conway, Brenda Burd

PII:

S0141-1136(08)00204-3

DOI:

10.1016/j.marenvres.2008.09.002

Reference:

MERE 3286

To appear in:

Marine Environmental Research

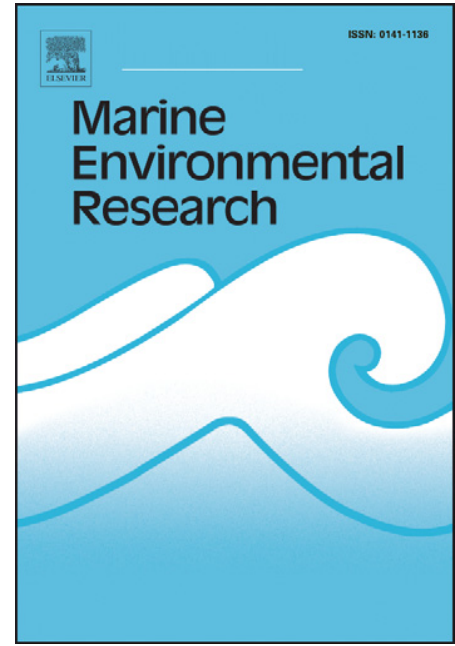

Received Date:

29 October 2007

Revised Date:

28 August 2008

Accepted Date:

2 September 2008

Please cite this article as: Cook, S.E., Conway, K.W., Burd, B., Status of the glass sponge reefs in the Georgia Basin, Marine Environmental Research (2008), doi: 10.1016/j.marenvres.2008.09.002

This is a PDF file of an unedited manuscript that has been accepted for publication. As a service to our customers we are providing this early version of the manuscript. The manuscript will undergo copyediting, typesetting, and review of the resulting proof before it is published in its final form. Please note that during the production process errors may be discovered which could affect the content, and all legal disclaimers that apply to the journal pertain. 


\section{Status of the glass sponge reefs in the Georgia Basin \\ Sarah E. Cook ${ }^{a, *}$, Kim W. Conway ${ }^{b}$ and Brenda Burd ${ }^{c}$}

西

a 1170 Cherry Rd., Victoria, British Columbia, V8Z $7 G 3$

${ }^{b}$ GSC Pacific (Sidney), Natural Resources Canada, 9860 West Saanich Road, Sidney, British Columbia, V8L 4B2

${ }^{c}$ Ecostat Research Ltd., 1040 Clayton Rd., N. Saanich, British Columbia, Canada, V8L 5P6

\section{Abstract}

1 The purpose of this paper is to describe the status and general faunal composition of sponge reefs in the Georgia Basin (GB), British Columbia, Canada. Fourteen distinct deep water glass sponge (Hexactinellid) reefs have been mapped using multibeam bathymetry and sidescan sonar in the GB. Seven of these have been surveyed visually using video from Remotely Operated Vehicles (ROVs). Analysis of video data indicated that three reefs were undamaged, two were damaged and the other two were damaged but potentially recovering. The nature of the damaged reefs, with large areas of scattered dead sponge skeleton fragments and few live reef-building sponges (Aphrocallistes vastus and Heterochone calyx), as well as video evidence of tracks suggest they were damaged mechanically by mobile fishing gear.

\footnotetext{
* Corresponding author. Tel.: (250) 381-8206

Email address: sarah_cook@shaw.ca (S.Cook).
} 
22 Relative abundance of the megafauna associated with the reefs is discussed in the

23 context of oceanographic conditions, such as sediment accumulation and organic flux, as

24 well as overall reef status. Of particular interest for fisheries conservation efforts in the

25 area was the fact that one undamaged reef in the southern GB showed higher taxonomic

26 richness and abundance of rockfish (Sebastes spp.), both adult and juvenile, compared

27 to an adjacent damaged reef. This result suggests that undamaged reefs may act as

28 refugia for these endangered stocks.

Keywords: Georgia Basin; Continental shelf; Glass sponge reefs; Hexactinellida; Multibeam;

32 Sidescan sonar; Effects - bottom trawling; Megafauna; Relative abundance; Reef status;

33 Rockfish 


\section{Introduction}

Glass sponge reefs built by sponges of Class Hexactinellida, Order Hexactinosida, are found along the continental shelf of the Pacific Northwest. Sponges of this order have a skeleton of fused silica spicules that remains remarkably intact after the death of the sponge (Krautter et al., 2006) and that can be used by sponge larvae for settlement.

These large, suspension-feeding animals act as baffles that slow currents at the seabed, causing entrained sediment to drop out of suspension (Krautter et al., 2006). This process results in the development of three-dimensional mound structures composed of massive, clay-rich sediments and siliceous sponge skeletons, with live reef-building sponges attached to exposed sponge skeletons on the reef surface (Conway et al., 2005a; Krautter et al., 2006). Individual reef mounds grow with time, and aggregations of these mounds form large reef complexes, which have been identified off British

Columbia, Canada, discontinuously covering over $700 \mathrm{~km}^{2}$ of the continental shelf in the Queen Charlotte Basin (QCB) (Conway et al., 1991; Krautter et al., 2001). A number of smaller complexes have also been described in the Georgia Basin (GB) (Conway et al., 2004; Conway et al., 2005a; Conway et al., 2007), and these are the focus of this paper.

1 The Strait of Georgia, which forms a large part of the Georgia Basin, is an enclosed body of water with moderately strong tidal currents and large fresh water input from the Fraser River. The Fraser River strongly influences sedimentation rates and organic flux in the GB (Burd et al., this issue; Hill et al., this issue). Multibeam mapping, geophysical surveys and textural data from grab samples indicate a complex pattern of sediment accumulation, transport and erosion in the southern strait (Barrie et al., 2005). The 
oceanographic and geologic settings of the reef complex on the Fraser Ridge (reef 1 ) and the McCall Bank complexes (reefs 2 - 4) (see Fig. 1 for locations) in the GB are described by Conway et al. (2004) and Conway et al. (2005a), respectively. The geologic setting of the reef complexes near the entrance to Active Pass in the GB is described by Conway et al. (2007).

The QCB reef complexes support diverse communities that are distinct from surrounding shelf communities and play a role as nursery habitats for rockfish (Sebastes spp.) (Cook, 2005). Rockfish are commercially important and have been subject to conservation efforts in recent years (DFO, 2006). Juvenile rockfish have been found at abundances five times higher on live reefs than on adjacent dead reef and off-reef areas in the QCB (Cook, 2005). Dead portions of the reefs, which are less structurally complex and mainly consist of sponge skeleton rubble, were also found to have significantly lower taxonomic richness and abundance of invertebrate fauna than live reef areas (Cook, 2005). There have not yet been any studies characterizing the community associated with the reef complexes in the GB.

The reef-building sponge species in the GB are Aphrocallistes vastus and Heterochone calyx. The reef-building species are found on gravel and rock substrates, such as glacial till ridges (Krautter et al., 2006), which can be found in very close proximity to the Fraser River on the Fraser Ridge (see Fig. 1) (Conway et al., 2004). The GB reef complexes are found in water depths of $90-300 \mathrm{~m}$ where bottom currents prevent sediment from accumulating (Conway et al., 2005a). The GB reefs grow in linear patterns along ridges, 
100 2. Materials and methods

101 2.1. Reef status

sometimes forming distinctive 'chevron' (Conway et al., 2007) or wave-form shapes (Conway et al., 2005a). The reef mounds in the GB have been recorded to heights of 14 m above the sea-floor (Conway et al., 2004; Conway et al., 2005a). 83

Sidescan sonar and video surveys in the QCB undertaken between 1991 and 2002 revealed that damage had been done to some of the reef complexes in areas heavily fished by bottom trawlers (Krautter et al., 2001; Conway et al., 2001). Fisheries and Oceans Canada closed the QCB reefs to bottom trawling in July 2002 in recognition of their susceptibility to the effects of fishing gear and is considering designating them as Marine Protected Areas (Jamieson and Chew, 2002).

O

Conway et al. (2007) qualitatively described the health of the sponge reef complexes 2 (healthy or unhealthy) in the GB; however, this was not a systematic description from the 3 video and the terms 'healthy' and 'unhealthy' were not defined. This study builds upon 4 that work with the goals of using a systematic analysis of the ROV video surveys to make 5 a preliminary assessment of the status, or condition, of the surveyed sponge reef complexes in the Georgia Basin, and of characterizing the megafaunal communities 7 associated with each. Possible reasons for status and differences in associated fauna 8 among reef complexes will be discussed. 
102 Sponge reefs in the GB were originally mapped using multibeam bathymetry and

103 sidescan sonar collected and analyzed to determine possible locations and extents of

104 sponge reef complexes in the GB (Conway et al., 2005a). In this paper, the status of the

105 reefs and their associated megafaunal organisms were assessed using video transects

106 collected by the Pacific Geoscience Centre between 2002 and 2006 (see Table 1).

107 These transects were collected using a digital video camera mounted on either a

108 Phantom HD2 Remotely Operated Vehicle (ROV) or the Remotely Operated Platform for

109 Ocean Science (ROPOS). Both vehicles had laser pointers mounted $10 \mathrm{~cm}$ apart that

110 were visible in the video. The remotely operated vehicle transects ranged from 420 to

$1115718 \mathrm{~m}$ in length, and the compiled video segments provide a transect for each complex.

112

113 The categories of reef status are: undamaged, damaged, damaged and possibly

114 recovering, and unknown. Observations of the condition of the reef-building sponges

115 were made along the on-reef portions of each transect, by recording estimates of percent

116 alive or dead as well as the condition of the dead sponge (standing or fragmented and

117 broken). Status was assigned based on the condition of the majority $(>50 \%)$ of the

118 transect. An undamaged reef consists mainly of areas of live reef-building sponges (Fig.

119 2a) (Aphrocallistes vastus and Heterchone calyx) and areas of standing dead sponge

120 (Fig. 2b) growing on mounds of dead sponge skeletons and skeletal fragments in a

121 sediment matrix. A damaged reef consists mainly of areas of broken and fragmented

122 dead sponge, possibly with small areas of standing dead sponge (Fig. 2c), and few

123 isolated live reef-building sponges. A damaged and possibly recovering reef consists of

124 mostly broken and fragmented dead sponge, but with widespread areas where young 
125 reef-building sponges are colonizing the fragmented, dead sponge skeletons (Fig. 2d).

126 Unknown status indicates that the reef complex has been identified but not yet surveyed

127 using video techniques.

128

\subsection{Associated Fauna}

130 The whole of each transect was viewed, and all visible megafauna were identified to the

131 lowest taxonomic level possible aided by digital photos taken by ROPOS (see Table 2).

132 Reef 4 was not included in this analysis, because the video became corrupted after the

133 reef status was determined. Each transect was divided into sections based on whether

134 the video was on-reef or off-reef. The abundance of organisms was recorded for the on-

135 reef sections in a semi-quantitative way, either by counting the number of individuals, or,

136 if the number of individuals was difficult to establish due to visibility, complex terrain or

137 very high abundance, by estimation. Counts and estimates were converted into a

138 measure of relative abundance (Few<Some<Many) for each reef complex, in recognition

139 of the fact that accurately quantifying some organisms was not feasible (criteria for the

140 conversion to relative abundance are described below; Table 2). The relative abundance

141 of different taxa is useful for comparing differences in faunal composition among reefs.

143 3. Results

144 3.1. Reef distribution and status

145 Fig. 1 shows the locations of reef complexes in the Georgia Basin as identified from

146 analysis of multibeam swath bathymetry data (Conway et al., 2007). Table 1 lists the reef

147 complexes by number, with geographic location, dive number, date surveyed and current 
148 status as determined from video analysis. The reefs are numbered in order of their

149 discovery (after Conway et al., 2007). Seven of the 14 identified reef complexes in the

150 GB have been surveyed visually.

151

152 Four of the seven surveyed reefs (3, 6, 9 and 13) were classified either as damaged (3

153 and 9), or as damaged and possibly recovering (6 and 13), based on video surveys. The

154 remaining three (1, 4 and 7$)$ were classified as undamaged.

155

156

\subsection{Associated fauna}

157 Table 2 presents the reef complexes on which each taxon was present. Only four taxa

158 were found on all six classified reef complexes for which there was usable video: spot

159 prawns (Pandalus platyceros), squat lobsters (Munida quadrispina), blood stars (Henricia

160 sp.) and ratfish (Hydrolagus colliel), which are all common species in British Columbia's

161 subtidal coastal waters (Cook, unpublished data from video surveys of B.C. coast). The

162 reef complex with the highest number of observed taxa (24) was undamaged reef 7 . Six

163 of the taxa at this reef complex were species of rockfish (Sebastes spp.). The lowest

164 number of taxa (8) was observed at reef complex 1 (undamaged). The damaged reef in

165 the southern part of the GB (reef 9) had 12 taxa, and the damaged reefs in the northern

166 GB (3, 6 and 13) had between 15 and 20 taxa each.

167

168 Table 3 includes relative abundance data for each of the taxonomic groups identified in

169 Table 2 for each reef complex. The northern group of reefs (3 (damaged), 6 and 13

170 (damaged and possibly recovering)) had the highest relative abundance of lyssacine 
171 sponges and demosponges, and was the only set of reefs where shortspine thornyheads

172 (Sebastolobus alascanus) were present. Brittle stars and sea urchins were only

173 observed at high relative abundance at reef 9 (damaged). Reef complex 7 (undamaged)

174 had the highest relative abundance of rockfish (Sebastes spp.). All other reefs had

175 relatively few rockfish. For example, 176 juvenile and adult rockfish were observed on

176 reef 7 (undamaged), and only 4 rockfish were observed on reef 9 (damaged). Corals,

177 mostly large Gorgonians, were observed on reefs 1 and 7 (both undamaged) in the

178 southern GB, although the highest abundance of corals was on reef 13 (damaged and

179 possibly recovering) in the northern GB.

180

181 4. Discussion

182 4.1. Reef distribution and status

183 Glass sponge reefs are distributed across a diverse range of oceanographic conditions

184 and depths in the Georgia Basin; however, more than half of the surveyed reef

185 complexes in the GB have been damaged. Reef-building glass sponges are brittle and

186 prone to fragmentation with physical contact. The nature of damaged reefs surveyed in

187 this study, with highly fragmented dead sponge skeleton and little or no standing dead

188 sponge, suggests that the reef complexes were damaged mechanically. It is well

189 documented that certain forms of fishing, such as bottom trawling, can cause this type of

190 damage to large sessile benthic fauna, including glass sponges on sponge reefs

191 (Krautter et al., 2001), other megafaunal sponges (Freese et al., 1999) and deep-water

192 corals (Hall-Spencer et al., 2002; Fosså et al., 2002; Reed et al., 2005). Sidescan sonar

193 data from damaged reef complex 3 shows relatively continuous and frequently parallel 
194 tracks or marks on the seabed (Fig. 3), which were likely left by mobile fishing gear, such

195 as heavy net doors on otter trawls. These marks have been described on reef

196 complexes in QCB in areas where the trawl fisheries are or have been active (Conway et

197 al., 2001; Krautter et al., 2001).

198

199 The presence of young reef-building sponges on damaged reefs 6 and 13 is evidence

200 that re-colonization can occur. Individual reef-building sponges were often observed

201 growing on bedrock or glacial till substrate adjacent to the damaged reefs (Fig. 4)

202 (Conway et al., 2007), and these off-reef areas could provide a source of larvae for re-

203 colonization. Possible recovery time for a reef complex can only be suggested based on

204 growth rates and size of the reef complexes. The reef-building sponge Aphrocallistes

205 vastus has a calculated mean growth rate of $1 \mathrm{~cm}$ per year and a maximum rate of $7 \mathrm{~cm}$

206 per year (Krautter et al., 2001, calculated from data in Levings and McDaniel, 1974). The

207 size of the reefs makes it likely that recovery would occur on a time scale of hundreds of

208 years (Conway et al., 2005b). Lyssacine glass sponges, such as Acanthascus

209 (Rhabdocalyptus) dawsoni, and encrusting and erect forms of demosponges, such as

210 Vulcanella sp. or Desmacella sp., also colonize dead sponge skeleton (Cook, 2005;

211 Lehnert et al., 2005). These taxa were observed on most of the damaged reefs,

212 suggesting that these sites are still capable of sustaining a large suspension feeding

213 community. It appears that lyssacine sponges can be primary colonizers of dead reefs,

214 which is not surprising since Acanthascus (Rhabdocalyptus) dawsoni has twice the mean

215 growth rate of Aphrocallistes vastus (Leys and Lauzon, 1998). However, there is 
216 currently no literature available on the progression of colonization on dead sponge

217 fragments.

219 Reef complex 1 (undamaged) is unique in that it is beneath the buoyant particulate plume

220 of the Fraser River. Although the ridge at reef complex 1 is a remnant glacial feature

221 rising above the sedimented basin, it is in an area with an unusually high sedimentation

222 rate (see Table 1 and Burd et al., this issue). Leys et al. (2004) and Farrow et al. (1983)

223 suggest that high sedimentation rates are associated with lower abundance of glass

224 sponges, since a sediment veneer can negatively affect the ability of glass sponges to

225 become established. In the case of reef complex 1, tidal currents are sufficiently strong

226 to keep sediment in suspension and the ridge surface non-depositional (Conway et al.,

227 2004), allowing glass sponges to colonize the gravel substrate. The reef mounds on the

228 ridge enlarge as growing sponges baffle the tidal currents and trap suspended sediment

229 (Krautter et al., 2006). The reef-building sponges on reef 1 were observed to be more

230 tube-shaped, with narrower oscula compared to the reef complexes in the QCB (Conway

231 et al., 2004) and to the other reefs in the GB. According to evidence from the fossil

232 record, a narrower osculum can compensate for increased sedimentation rates and

233 reduce the amount of sediment trapped in the sponge cavity. This adaptation helps to

234 prevent sediment from overwhelming cleaning mechanisms, which can cause the death

235 of the sponge (Conway et al., 2004). The presence of a healthy sponge reef beneath the

236 Fraser River plume shows that these organisms can adapt to unusual sedimentation

237 conditions, if current regime, seabed sediment transport rates, temperature, and

238 dissolved oxygen and silica levels are suitable (Leys et al., 2004; Whitney et al., 2005). 
240 The most recently discovered reef complex (14 in Howe Sound, see Fig. 1 for location)

241 was identified by Natural Resources Canada personnel (unpublished data, 2008),

242 subsequent to the publication of the discovery of the other sponge reefs by Conway et al.

243 (2007). Reef complex 14 appears to be undamaged; however, ROV survey videos of

244 that reef have not yet been analyzed and further work will be required to assess the

245 status of this reef complex and its associated faunal community.

\subsection{Associated fauna}

248 Reef-building sponges appear to be foundation species, as defined by Dayton (1975),

249 since they are organisms that create habitat for other organisms, and thereby exert a

250 disproportionately large influence on community structure. Therefore, fauna associated

251 with the reefs could be affected by changes to the status of the reef. To determine the

252 effect of reef status on the associated community, a comparison was made between

253 reefs 7 (undamaged) and 9 (damaged) in the southern basin, which are located close

254 together ( 8 km apart) and were surveyed only days apart. The higher number of taxa

255 and greater abundance of both adult and juvenile rockfish at reef 7 (undamaged) is

256 consistent with published results that link increased habitat complexity, or structural

257 heterogeneity, to increased taxonomic richness and abundance of individuals (Crowder

258 and Cooper, 1982; Diehl, 1992; Garcia-Charton and Perez-Ruzafa, 1998; Wyda et al.,

259 2002; Garcia-Charton et al., 2004). It is therefore likely that undamaged sponge reefs in

260 the GB can provide refugia for adult rockfish and a nursery habitat for juveniles, as found

261 in the QCB (Cook, 2005). However, it should be noted that the other undamaged reef 
262 where fauna were assessed (reef 1), had the lowest number of taxa of all the surveyed

263 reefs. This result seems inconsistent with the supposition that sponge reefs in the GB

264 are refugia supporting enhanced bio-diversity. However, as mentioned in section 4.1,

265 this reef complex is in a unique oceanographic setting, with a high concentration of

266 suspended sediment and a high sedimentation rate, which may be less than ideal for the

267 settlement of other sessile species typically associated with the reefs. Regional

268 variations in physical and biological factors have been shown to affect the distribution and

269 abundance of fish assemblages (Garcia-Charton et al., 2004); the same may be true for

270 invertebrate fauna. A statistically rigorous comparison of reef fauna between damaged

271 and undamaged reefs was not possible using this dataset; however these results provide

272 a preliminary basis for more in-depth assessment of the reefs in the future.

274 Reef 6 (damaged, possibly recovering) had the highest number of taxa of the northern

275 GB complexes. Unfortunately, there were no undamaged reefs in the northern GB on

276 which the fauna could be assessed for this study, so it cannot be determined whether the

277 taxonomic richness observed on reef 6 was typical of the area. Reef 13 (damaged,

278 possibly recovering), also in the northern GB, had a higher relative abundance of sessile

279 filter feeders than did the other reef complexes. Hydrodynamic conditions or biological

280 factors, such as abundance of suspended food particles, may encourage settlement of

281 these sessile filter feeders at damaged reef sites.

282

283 One of the consequences of trawling damage is to decrease habitat complexity (Watling 284 and Norse, 1998; Kaiser et al., 2000). This could be especially detrimental for the juvenile 
285 fish that use these complex structural habitats. For example, it was observed that the 286 shortspine thornyheads (Sebastolobus alascanus) on the damaged reefs in the northern

287 GB, which were almost all in the juvenile to intermediate colour phase (Love et al., 2002), 288 were frequently observed within or near the scattered areas of higher relief, such as 289 patches of standing dead sponge. Juvenile rockfish (Sebastes spp.) also have an affinity

290 for structurally complex habitats (O'Connell and Carlile, 1994; Cote et al., 2003; Diaz et 291 al., 2003). Rockfish are a dwindling fisheries resource throughout the Pacific Northwest

292 and have been the focus of conservation initiatives in recent years (Ralston, 1998;

293 Musick et al., 2000; Yamanaka, 2000; DFO, 2006). Protection of refugia and nursery

294 habitat, such as sponge reefs, would be consistent with this conservation strategy

295 (Yoklavich, 1997).

296

\section{5. Conclusions}

298 The sponge reefs in the GB exist in a range of bathymetric settings and oceanographic conditions, and are distributed throughout the GB. Over half of the reefs that have been

300 visually surveyed show significant damage, likely by fishing activities, such as bottom

301 trawling. The damaged reefs appear to be capable of recovery, although the time

302 required for sponge and reef re-growth is unknown. Undamaged reefs appear to have 303 the potential to act as refugia and nursery habitat for commercially valuable fish species.

304 Trawl closures have been implemented as a fisheries management measure at the large 305 sponge reef complexes in the Queen Charlotte Basin in recognition of their fragile nature and importance to fisheries resources; similar protection may be warranted for the sponge reefs in the Strait of Georgia. 


\section{Acknowledgments}

310 Funding for this study was provided through the Ambient Monitoring Program for the

311 southern Strait of Georgia, which arises from a collaborative agreement between the

312 Department of Fisheries and Oceans, Metro Vancouver (formerly the Greater Vancouver

313 Regional District) and Natural Resources Canada. 


\section{References}

316 Barrie, J.V., Hill, P.R., Conway, K.W., Iwanowska, K., Picard, K., 2005. Georgia Basin:

317 Seabed features and marine geohazards. Geoscience Canada 32, 145-156.

318 Burd, B., Macdonald, R., Johannessen, S., van Roodselaar, A., this issue. Responses of 319 subtidal benthos of the Strait of Georgia to ambient sediment conditions and natural and anthropogenic depositions. Marine Environmental Research, this issue.

321 Conway, K.W., Barrie, J.V., Austin, W.C., Luternauer, J.L., 1991. Holocene sponge

322 bioherms on the western Canadian continental shelf. Continental Shelf Research 11, $323 \quad 771-790$.

324 Conway, K.W., Krautter, M., Barrie, J.V., Neuweiler, M., 2001. Hexactinellid sponge reefs on the Canadian continental shelf: a unique 'living fossil'. Geoscience Canada 28, 7178.

Conway, K.W., Barrie, J.V., Krautter, M., 2004. Modern siliceous sponge reefs in a turbid siliciclastic setting: Fraser River delta, British Columbia, Canada. Neues Jahrbuch für Geologie und Paläontologie 2004, 335-350.

330 Conway, K.W., Barrie, J.V., Krautter, M., 2005. Geomorphology of unique reefs on the western Canadian shelf: sponge reefs mapped by multibeam bathymetry. Geo-Marine

333 Conway, K.W., Krautter, M., Barrie, J.V., Whitney, F., Thomson, R.E., Reiswig, H., 334 Lehnert, H., Mungov, G., Bertram, M., 2005. Sponge reefs in the Queen Charlotte 335 Basin, Canada: controls on distribution, growth and development. In: Freiwald, A., 
Roberts, J.M. (Eds.), Cold-water Corals and Ecosystems. Springer-Verlag, Berlin, Germany, pp. 605-621.

Conway, K.W., Barrie, J.V., Hill, P.R., Austin, W.C., Picard, K., 2007. Mapping sensitive benthic habitats in the Strait of Georgia, coastal British Columbia: deep-water sponge and coral reefs. Geological Survey of Canada, Current Research 2007-A2, 6pp.

Cook, S.E., 2005. Ecology of the Hexactinellid sponge reefs on the Western Canadian continental shelf. M.Sc. thesis, University of Victoria, Victoria, Canada, 127pp.

Cote, D., Ollerhead, L.M.N., Scruton, D.A., McKinley, R.S., 2003. Microhabitat use of 344 juvenile Atlantic cod in a coastal area of Newfoundland determined by 2D telemetry. Marine Ecology Progress Series 265, 227-234.

346 Crowder, L.B., Cooper, W.E., 1982. Habitat structural complexity and the interaction between bluegills and their prey. Ecology 63, 1802-1813.

348 Dayton, P. K., 1975. Experimental evaluation of ecological dominance in a rocky intertidal algal community. Ecological Monographs 45, 137-159.

DFO, 2006. Rockfish conservation areas: protecting British Columbia's rockfish. Fisheries and Oceans Canada, Pacific Region, Vancouver, Canada, Fs144-1/2006E, 177pp.

Diaz, R. J., Cutter, G.R. Jr., Able, K.W., 2003. The importance of physical and biogenic structure to juvenile fishes on the shallow inner continental shelf. Estuaries 26, 12-20.

Diehl, S., 1992. Fish predation and benthic community structure: the role of omnivory and

356 Farrow, G.E., Syvitski, J.P.M., Tunnicliffe, V., 1983. Suspended particulate loading on 357 the macrobenthos in a highly turbid fjord: Knight Inlet, British Columbia. Canadian 358 Journal of Fisheries and Aquatic Sciences 40, 273-288. 
359 Fosså, J. H., Mortensen, P.B., Furevik, D.M., 2002. The deep-water coral Lophelia pertusa in Norwegian waters: distribution and fishery impacts. Hydrobiologia 471, 112.

362 Freese, L., Auster, P.J., Heifetz, J., Wing, B.L., 1999. Effects of trawling on seafloor 363 habitat and associated invertebrate taxa in the Gulf of Alaska. Marine Ecology Progress Series 182, 119-126.

Garcia-Charton, J.A., Perez-Ruzafa, A., 1998. Correlation between habitat structure and a rocky reef fish assemblage in the Southwest Mediterranean. Marine Ecology 19, $111-128$.

Garcia-Charton, J.A., Perez-Ruzafa, A., Sanchez-Jerez, P., Sempere-Bayle, J.T., Renones, O., Moreno, D., 2004. Multi-scale spatial heterogeneity, habitat structure, and the effect of marine reserves on Western Mediterranean rocky reef fish assemblages. Marine Biology 144, 161-182.

Hall-Spencer, J., Allain, V., Fosså, J.H., 2002. Trawling damage to Northeast Atlantic ancient coral reefs. Proceedings of the Royal Society of London Part B 269, 507-511. Hill, P.R., Conway, K., Lintern, D.G., Meulé, S., Picard, K., Barrie, J.V., this issue. Sedimentary processes and sediment dispersal in the southern Strait of Georgia, BC, Canada. Marine Environmental Research, this issue.

Jamieson, G.S., Chew, L., 2002. Hexactinellid sponge reefs: areas of interest as marine protected areas in the North and Central Coast areas. Canadian Science Advisory Secretariat Research Document 2002/122, 77pp.

Kaiser, M. J., Spence, F.E., Hart, P.J.B., 2000. Fishing-gear restrictions and conservation of benthic habitat complexity. Conservation Biology 14, 1512-1525. 
382 Krautter, M., Conway, K.W., Barrie, J.V., 2001. Discovery of a "living dinosaur": globally 383 unique modern Hexactinellid sponge reefs off British Columbia, Canada. Facies 44, 265-282.

Krautter, M., Conway, K.W., Barrie, J.V., 2006. Recent Hexactinosidan sponge reefs (silicate mounds) off British Columbia, Canada: frame-building processes. Journal of Paleontology 80, 38-48.

Lehnert, H., Conway, K.W., Barrie, J.V., Krautter, M., 2005. Desmacella austini sp. nov. from sponge reefs off the Pacific coast of Canada. Contributions to Zoology 74, 265270.

Levings, C.D., McDaniel, N.G., 1974. A unique collection of baseline biological data: benthic invertebrates from an underwater cable across the Strait of Georgia. Fisheries Research Board of Canada, Technical Report 441, 19pp.

Leys, S.P., Lauzon, N.R.J., 1998. Hexactinellid sponge ecology: growth rates and seasonality in deep water sponges. Journal of Experimental Marine Biology and Ecology 230, 111-129.

Leys, S.P., Wilson, K., Holeton, C., Reiswig, H.M., Austin, W.C., Tunnicliffe, V., 2004. Pacific. University of California Press, Berkeley, U.S.A., 414pp. 
405

406

407

408

409

410

411

412

413

414

415

416

Marine, estuarine, and diadromous fish stocks at risk of extinction in North America (exclusive of Pacific salmonids). Fisheries 25, 6-10.

O'Connell, V.M., Carlile, D.W., 1994. Comparison of a remotely operated vehicle and a submersible for estimating abundance of demersal shelf rockfishes in the Eastern Gulf of Alaska. North American Journal of Fisheries Management 14, 196-201.

Ralston, S., 1998. The status of federally managed rockfish on the U.S West Coast. In: Yoklavich, M.M. (Ed.), Marine harvest refugia for West Coast rockfish: A workshop. NOAA Technical Memorandum NMFS, pp. 6-10.

Reed, J.K., Shepard, A.N., Koenig, C.C., Scanlon, K.M., Gilmore, Jr., R.G., 2005. Mapping, habitat characterization, and fish surveys of the deep-water Oculina coral reef Marine Protected Area: a review of historical and current research. In: Freiwald, A., Roberts, J.M. (Eds.), Cold-water Corals and Ecosystems. Springer-Verlag, Berlin, Germany, pp. 443-465.

Watling, L., Norse, E.A., 1998. Disturbance of the seabed by mobile fishing gear: a comparison to forest clearcutting. Conservation Biology 12, 1180-1197.

Whitney, F., Conway, K., Thomson, R., Barrie, V., Krautter, M., Mungov, G., 2005. Oceanographic habitat of sponge reefs on the Western Canadian Continental Shelf. Continental Shelf Research 25, 211-226.

Wyda, J. C., Deegan, L.A., Hughes, J.E., Weaver, M.J., 2002. The Response of fishes to submerged aquatic vegetation complexity in two ecoregions of the Mid-Atlantic Bight: Buzzards Bay and Chesapeake Bay. Estuaries 25, 86-100. 
426 Yamanaka, K.L., 2000. Inshore rockfish: Pacific Region DFO Science Stock Status

427 Report. Stock Status Report A6-16, Fisheries and Oceans Canada, Nanaimo, $428 \quad$ Canada, 3pp.

429 Yoklavich, M.M., 1997. Applications of sidescan sonar and in situ submersible survey 430 techniques to marine fisheries habitat research. In. Boehlet, G.W., Schumacher, J.D.

431 (Eds.), Changing oceans and changing fisheries: environmental data for fisheries

432 research and management. NOAA Technical Memorandam NMFS, pp. 140-141. 


\section{Figure Titles}

Fig. 1. Location of known glass sponge reef complexes in the Georgia Basin. They are numbered in order of discovery by multibeam swath bathymetry surveys conducted by the Geological Survey of Canada (after Conway et al., 2007). Only six complexes $(1,3,6,7,9,13)$ have been surveyed using visual techniques.

Fig. 2. A) Dense live reef-building sponges (undamaged reef 7), B) Standing dead sponge skeleton (damaged and possibly recovering reef 13). Crimson anemones (Cribrinopsis fernaldi), boot sponges (Rosselid sponges) and a small reef building sponge are attached, C) Fragmented dead sponge skeleton spread over the seabed (damaged reef 9), D) Small reef-building sponges attached to fragmented dead sponge skeleton (damaged but possibly recovering reef 6 ). Several tube-dwelling anemones (Pachycerianthus fimbriatus) are also present.

Fig. 3. Sidescan sonar and interpretation from reef complex 3 (McCall Bank) showing parallel lines in the reef surface that are interpreted as the marks left from the heavy doors of bottom trawl gear.

Fig. 4. Reef-building sponges growing on glacial till adjacent to the reef complexes in the McCall Bank area. 


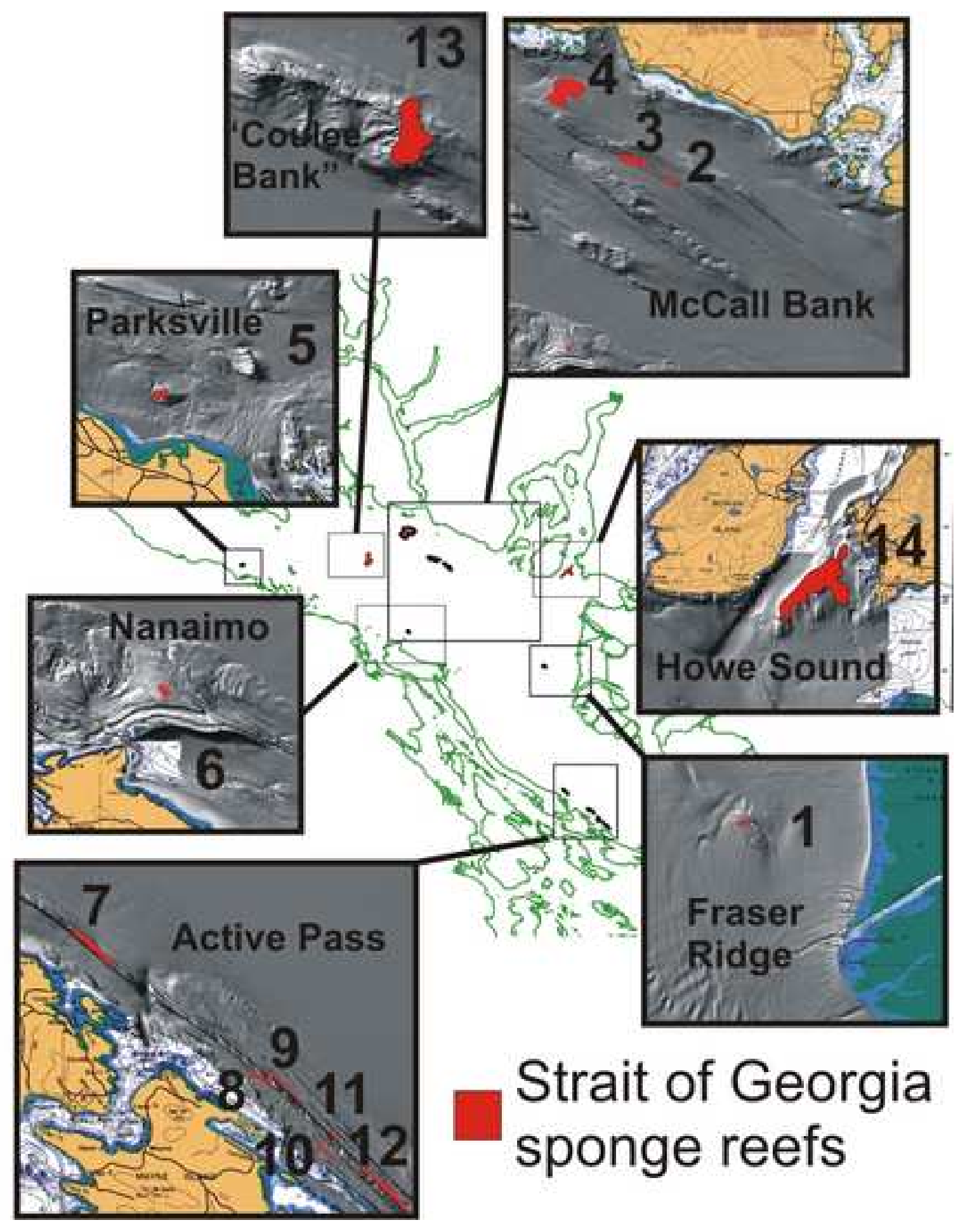




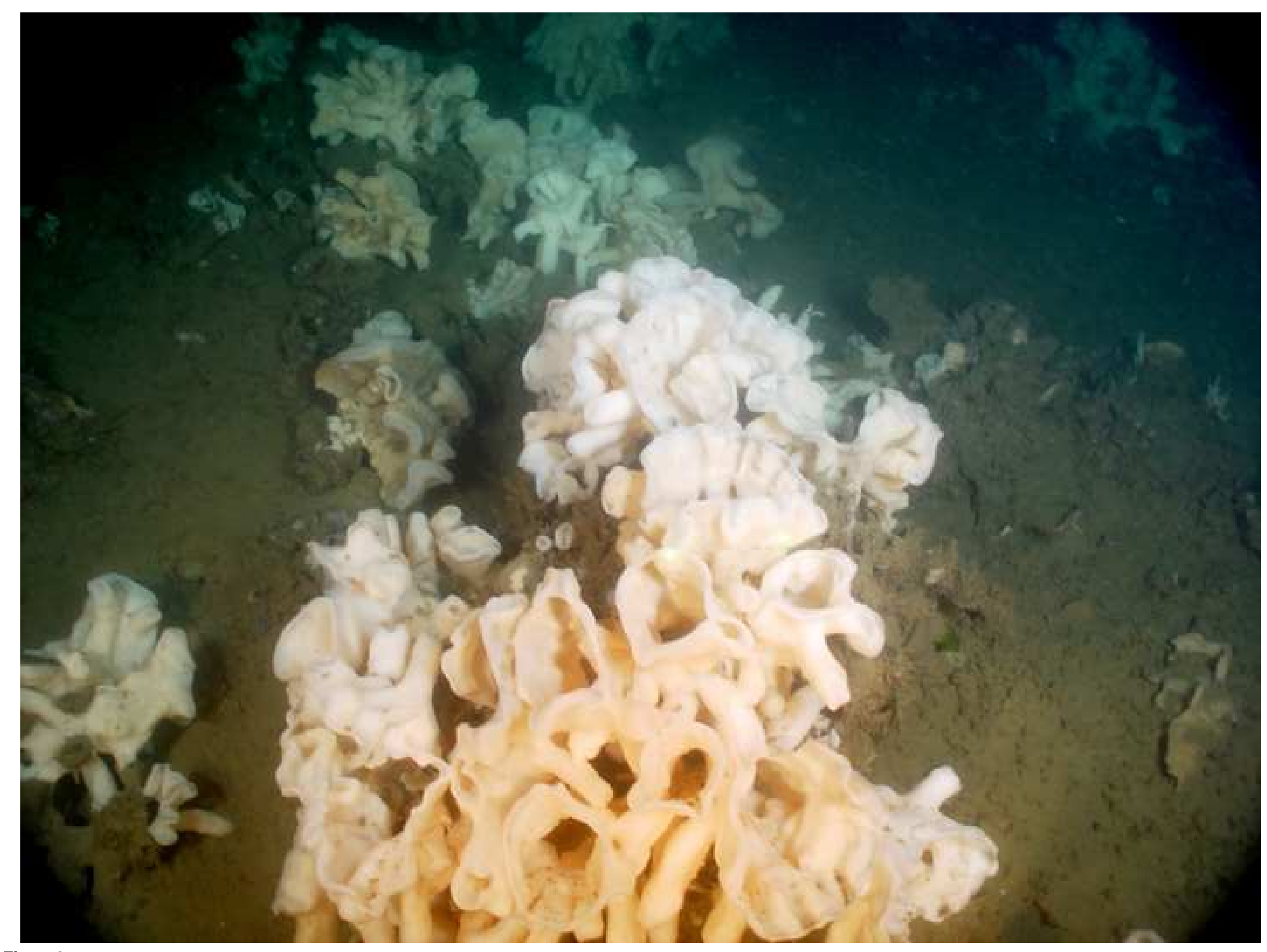




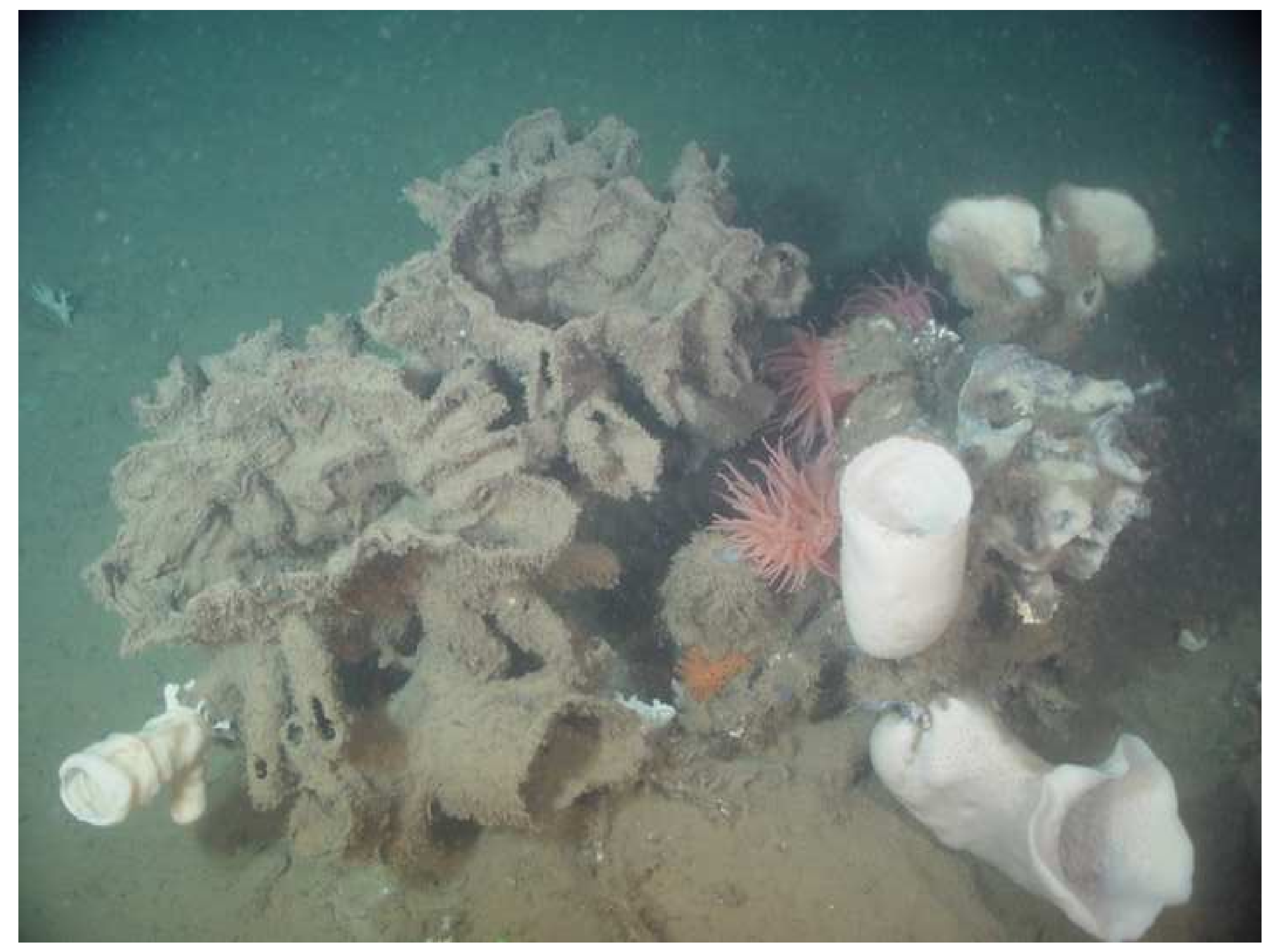

Figure2b 


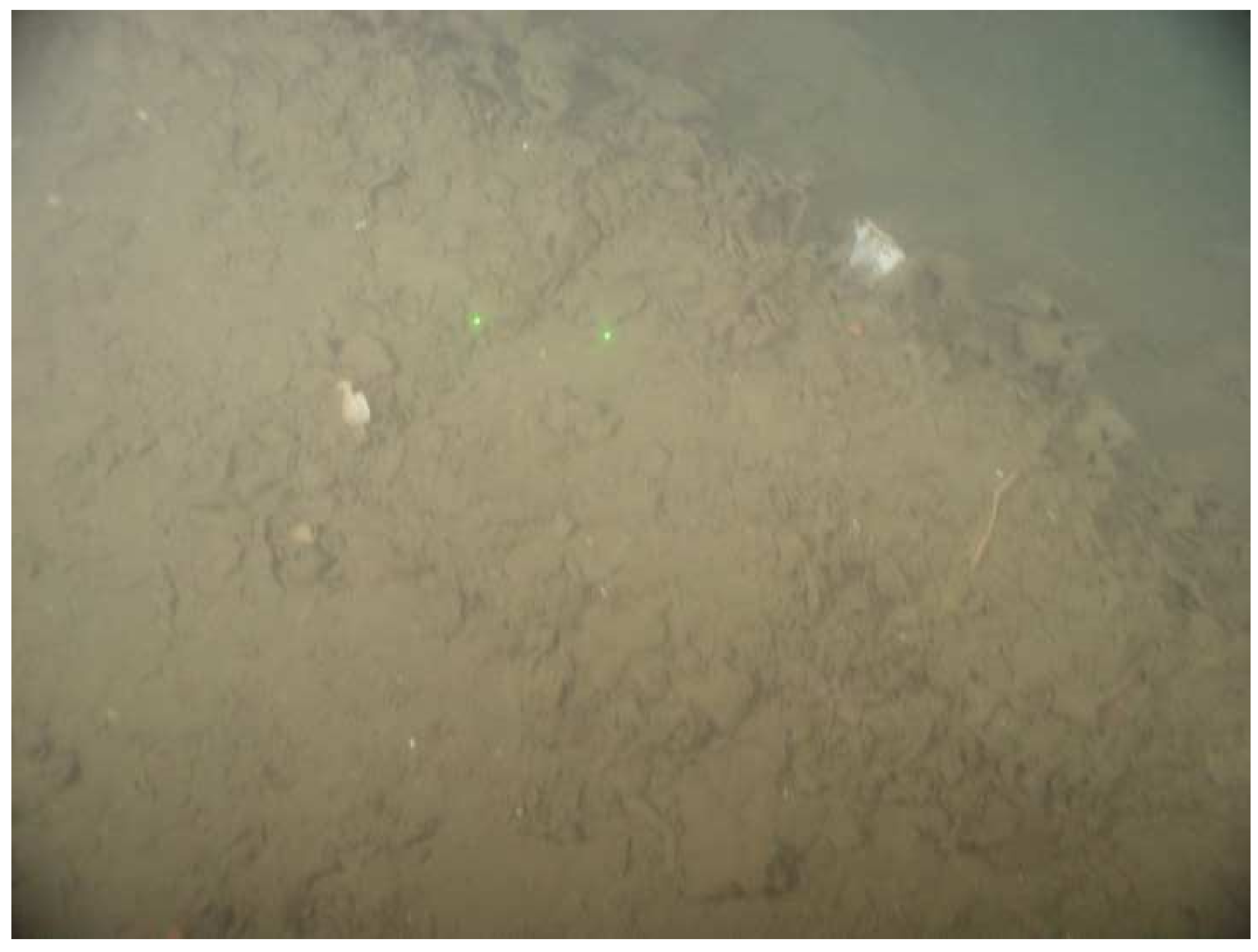

Figure2c 


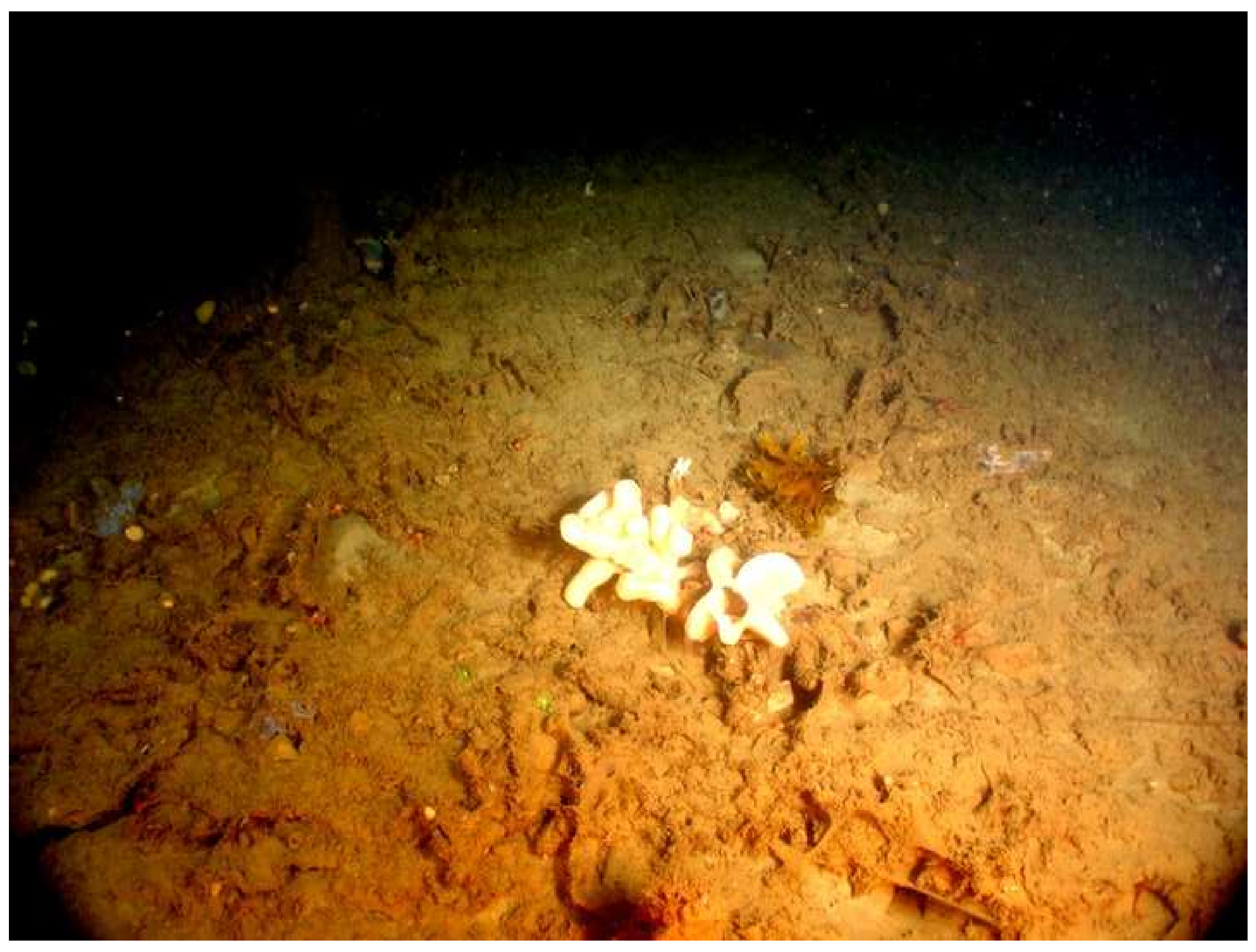

Figure2d 


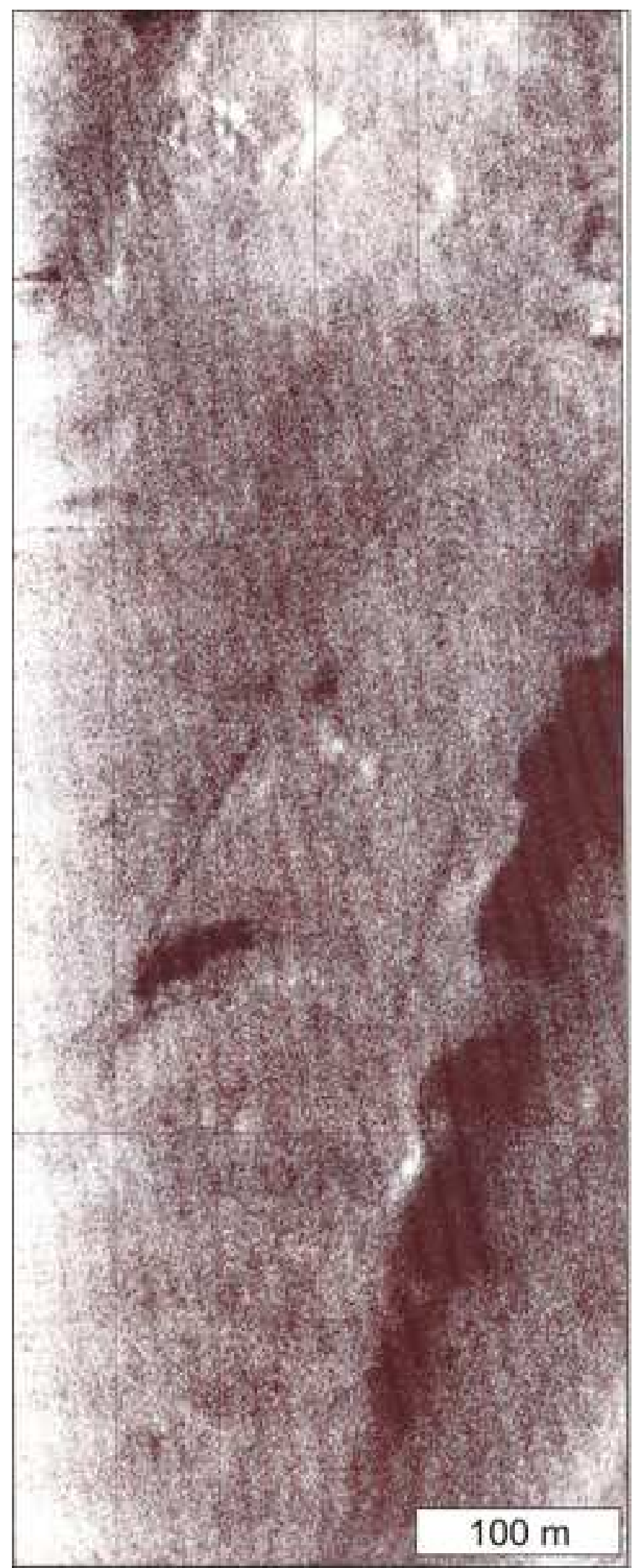

sponge reef surface

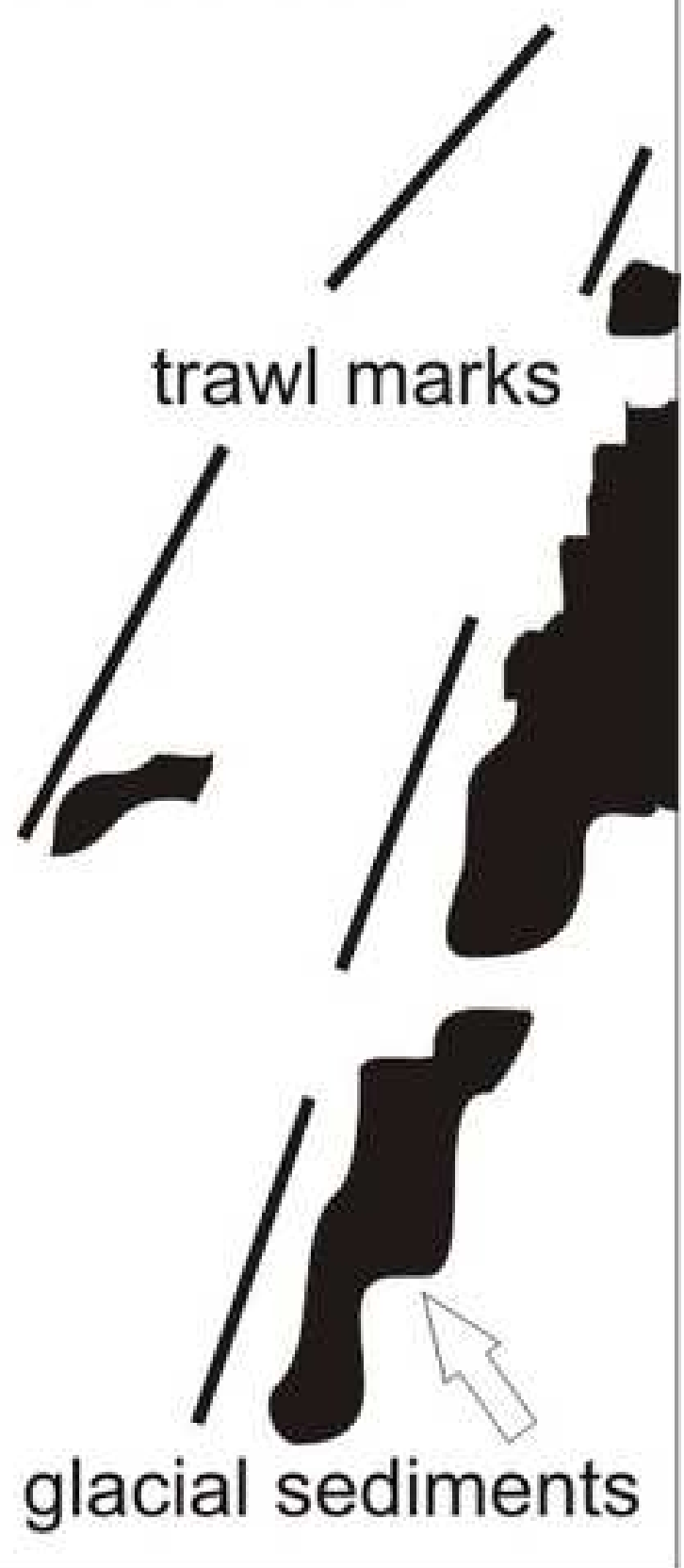

Figure3 


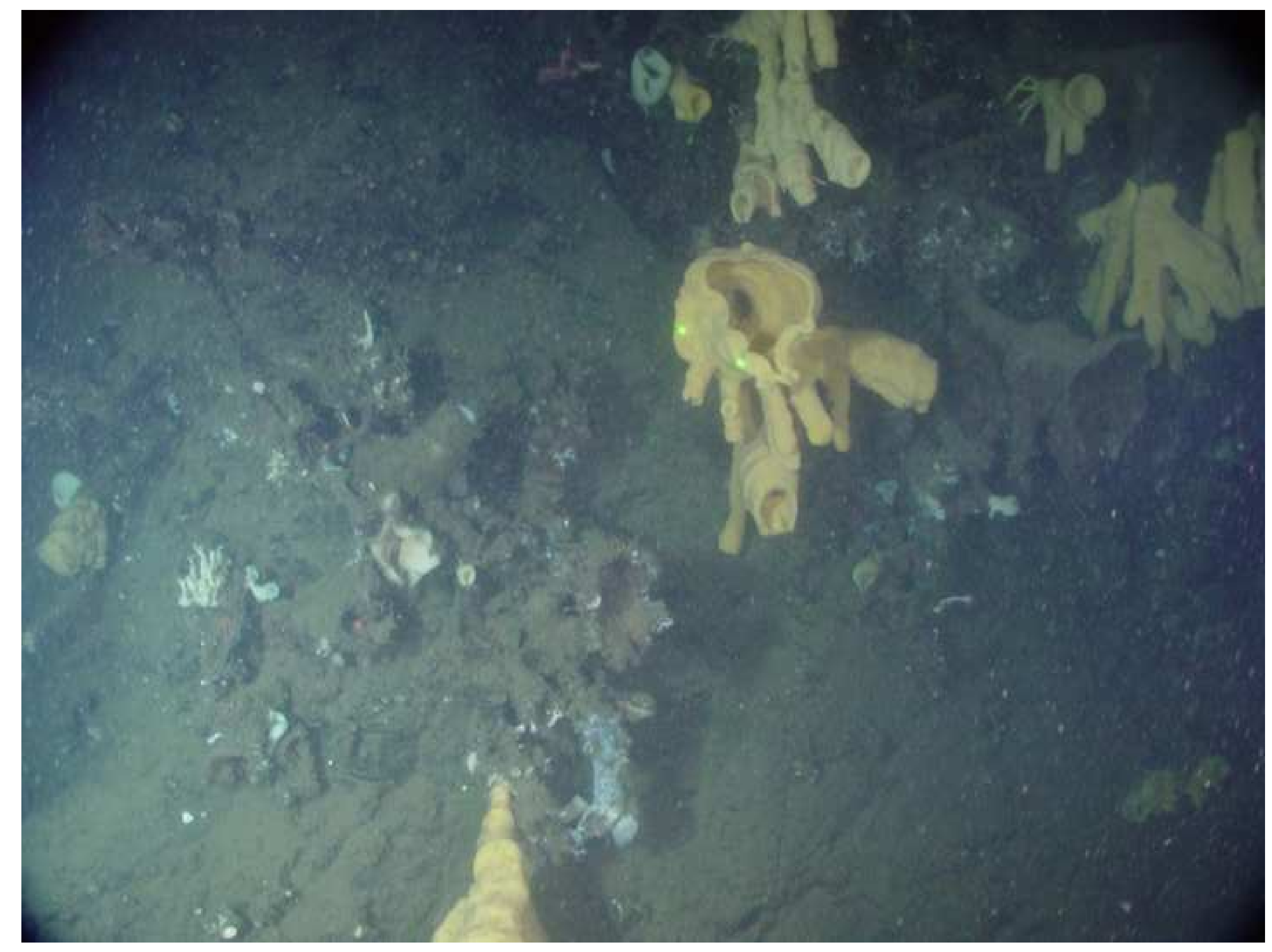


1 Table 1

2 Current status of the glass sponge reefs in the Georgia Basin. The reef complexes are numbered in order of their

3 discovery, after Conway et al. (2007).

\begin{tabular}{|c|c|c|c|c|c|c|c|c|c|}
\hline $\begin{array}{c}\text { Reef } \\
\text { Complex }\end{array}$ & $\begin{array}{l}\text { Geographic } \\
\text { Location }\end{array}$ & Dive Number & $\begin{array}{c}\text { Date } \\
\text { Sampled } \\
\text { (Video) }\end{array}$ & Status $^{\dagger}$ & $\begin{array}{c}\text { Depth } \\
\text { Range }(\mathrm{m})\end{array}$ & $\begin{array}{l}\text { Duration } \\
\text { (min) }\end{array}$ & $\begin{array}{c}\text { Distance } \\
(\mathrm{m})\end{array}$ & $\begin{array}{c}\text { Sedimentation } \\
\text { Rate }^{*} \\
\left(\mathrm{~g} / \mathrm{cm}^{2} / \mathrm{yr}\right)\end{array}$ & $\begin{array}{c}\text { Organic } \\
\text { Flux }{ }^{* *} \\
\left(\mathrm{mgC} / \mathrm{cm}^{2} / \mathrm{yr}\right)\end{array}$ \\
\hline 1 & Fraser Ridge & $\begin{array}{l}\text { PGC02004, } \\
\text { dives 1-4 }\end{array}$ & July 2002 & Undamaged & $150-190$ & 371 & 3470 & $>4$ & $>30$ \\
\hline 2 & McCall Bank & $\mathrm{N} / \mathrm{A}$ & $\mathrm{N} / \mathrm{A}$ & Unknown & $120-210$ & & & $<0.75$ & $<15$ \\
\hline 3 & McCall Bank & $\begin{array}{l}\text { ROPOS } \\
\text { dive } 760\end{array}$ & $\begin{array}{l}\text { October } \\
2003\end{array}$ & Damaged & $120-210$ & & 3244 & $<0.75$ & $<15$ \\
\hline 4 & McCall Bank & $\begin{array}{l}\text { ROPOS } \\
\text { dive } 761\end{array}$ & $\begin{array}{l}\text { October } \\
2003\end{array}$ & Undamaged $^{\ddagger}$ & $90-210$ & & 663 & $<0.75$ & $<15$ \\
\hline 5 & Parksville & $\mathrm{N} / \mathrm{A}$ & $\mathrm{N} / \mathrm{A}$ & Unknown & $90-110$ & & & $<0.75$ & $<15$ \\
\hline 6 & Nanaimo & $\begin{array}{l}\text { ROPOS } \\
\text { dive } 873\end{array}$ & $\begin{array}{l}\text { November } \\
2004\end{array}$ & $\begin{array}{l}\text { Damaged, } \\
\text { possibly } \\
\text { recovering }\end{array}$ & $110-150$ & 154 & 5718 & $<0.75$ & $<15$ \\
\hline 7 & $\begin{array}{l}\text { Active Pass } \\
\text { North }\end{array}$ & $\begin{array}{l}\text { ROPOS } \\
\text { dive } 930\end{array}$ & $\begin{array}{l}\text { October } \\
2005\end{array}$ & Undamaged & 95-105 & 171 & 1920 & $>2.5$ & $>25$ \\
\hline 8 & $\begin{array}{l}\text { Active Pass } \\
\text { South }\end{array}$ & N/A & $\mathrm{N} / \mathrm{A}$ & Unknown & $90-100$ & & & $>2.5$ & $>25$ \\
\hline 9 & $\begin{array}{l}\text { Active Pass } \\
\text { South }\end{array}$ & $\begin{array}{l}\text { ROPOS } \\
\text { dive } 931\end{array}$ & $\begin{array}{l}\text { October } \\
2005\end{array}$ & Damaged & $120-140$ & 154 & 1770 & $>2.5$ & $>25$ \\
\hline 10 & $\begin{array}{l}\text { Active Pass } \\
\text { South }\end{array}$ & $\mathrm{N} / \mathrm{A}$ & N/A & Unknown & $90-100$ & & & $>2.5$ & $>25$ \\
\hline 11 & $\begin{array}{l}\text { Active Pass } \\
\text { South }\end{array}$ & $\mathrm{N} / \mathrm{A}$ & $\mathrm{N} / \mathrm{A}$ & known & $100-110$ & & & $>2.5$ & $>25$ \\
\hline 12 & $\begin{array}{l}\text { Active Pass } \\
\text { South }\end{array}$ & $\mathrm{N} / \mathrm{A}$ & $\mathrm{N} / \mathrm{A}$ & Unknown & $100-130$ & & & $>2.5$ & $>25$ \\
\hline 13 & "Coulee Bank" & $\begin{array}{l}\text { ROPOS } \\
\text { dive } 1029\end{array}$ & $\begin{array}{l}\text { November } \\
2006\end{array}$ & $\begin{array}{l}\text { Damaged, } \\
\text { possibly } \\
\text { recovering }\end{array}$ & $240-290$ & 211 & 4780 & $<0.75$ & $<15$ \\
\hline 14 & Howe Sound & $\mathrm{N} / \mathrm{A}$ & $\mathrm{N} / \mathrm{A}$ & Unknown & $50-160$ & & & $<0.75$ & $<10$ \\
\hline
\end{tabular}

5 Fescribed as undamaged in Conway et al. (2005a); however the video was corrupted so faunal associations were not assessed.

$6 \quad$ *Estimated from figures in Burd et al. (this issue) and Hill et al. (this issue).

$7{ }^{* *}$ Estimated from figure in Burd et al. (this issue). 
Table 2

12 All observed megafaunal fish and invertebrate taxa as identified to the lowest taxonomic level possible, rolled into higher 13 level taxonomic groups. The reef complexes each taxon was observed on is listed.

\begin{tabular}{|c|c|c|c|c|c|}
\hline Taxonomic Group & Phylum & Class & Taxa & Common Name & $\begin{array}{c}\text { Reef } \\
\text { Complexe }\end{array}$ \\
\hline \multirow[t]{2}{*}{ Anemones } & Cnidaria & Anthozoa & Cribrinopsis fernaldi & Crimson Anemone & $1,3,7,9,13$ \\
\hline & & & Pachycerianthus fimbriatus & Tube-Dwelling Anemone & $1,7,13$ \\
\hline \multirow[t]{3}{*}{ Corals } & Cnidaria & Anthozoa & Order Gorgonacea & Gorgonean Corals & 13 \\
\hline & & & Poss. Lophelia pertusa & & 1 \\
\hline & & & & Hydrocorals & 7 \\
\hline Hydroids & Cnidaria & Hydrozoa & & Hydroids & 6,13 \\
\hline Lyssacine Sponges & Porifera & Hexactinellida & Order Lyssacinosida & Boot Sponges & $1,3,6,7,13$ \\
\hline \multirow[t]{3}{*}{ Demosponges } & Porifera & Demospongiae & lophon (?) sp. & Finger Sponge & $3,6,13$ \\
\hline & & & Vulcanella sp. & Plate Sponge & 3,6 \\
\hline & & & Stylissa sp. & Trumpet Sponge & 7 \\
\hline \multirow[t]{2}{*}{ Gastropods } & Mollusca & Gastropoda & Suborder Doridacea & White Dorid Nudibranch & 3 \\
\hline & & & Fusitriton oregonensis & Oregon Whelk & 7 \\
\hline Squat Lobsters & Arthropoda & Malacostraca & Munida quadrispina & Squat Lobster & All \\
\hline \multirow[t]{3}{*}{ Other Crustaceans } & Arthropoda & Malacostraca & Oregonia sp. & Decorator crabs & 3,7 \\
\hline & & & Pandalus platyceros & Spot Prawn & All \\
\hline & & & Lopholithodes sp. & Box Crab & 6,7 \\
\hline \multirow[t]{4}{*}{ Seastars } & Echinodermata & Asteroidea & Ceramaster patagonicus & Cookie Star & $3,6,7,13$ \\
\hline & & & Family Goniasteridae & & $3,6,9,13$ \\
\hline & & & Henricia sp. & Blood Stars & All \\
\hline & & & Pteraster tesselatus & Cushion Star & $3,6,7,9$ \\
\hline Sea Urchins & Echinodermata & Echinoidea & Strongylocentrotus sp. & & 7,9 \\
\hline Brittle Stars & Echinodermata & Ophiuroidea & & Brittle Stars & 9 \\
\hline \multirow[t]{7}{*}{ Rockfish } & Chordata & Osteichthyes & Sebastes sp. & Rockfish & 7,9 \\
\hline & & & Sebastes elongatus & Greenstriped Rockfish & $3,6,7$ \\
\hline & & & Sebastes flavidus & Yellowtail Rockfish & 7 \\
\hline & & & Sebastes maliger & Quillback Rockfish & 6,7 \\
\hline & & & Sebastes miniatus & Vermillion Rockfish & 6 \\
\hline & & & Sebastes proriger & Redstripe Rockfish & 7 \\
\hline & & & Sebastes ruberrimus & Yelloweye Rockfish & $3,7,9$ \\
\hline Thornyheads & Chordata & Osteichthyes & Sebastolobus alascanus & Shortspine Thornyhead & $3,6,13$ \\
\hline \multirow[t]{4}{*}{ Other Fish } & Chordata & Osteichthyes & Family Agonidae & Poachers & 7 \\
\hline & & & Family Gadidae & Codfish & $6,7,13$ \\
\hline & & & Family Pleuronectidae & Flatfish & $3,6,7,9$ \\
\hline & & & Ophiodon elongatus & Lingcod & 6 \\
\hline \multirow[t]{3}{*}{ Cartilagenous Fish } & Chordata & Chondrichthyes & Hydrolagus colliei & Ratfish & All \\
\hline & & & Squalus acanthias & Dogfish & $3,6,13$ \\
\hline & & & Family Rajidae & Skates & 3 \\
\hline
\end{tabular}


Table 3

Relative abundance of invertebrate groups between surveyed reef complexes ( $F=F e w<S=S o m e<M=M a n y)$. A line indicates none were observed. Measure indicates whether individuals were counted $(C)$ or estimated (E). Criteria for converting estimates and counts into a relative abundance is given below the table.

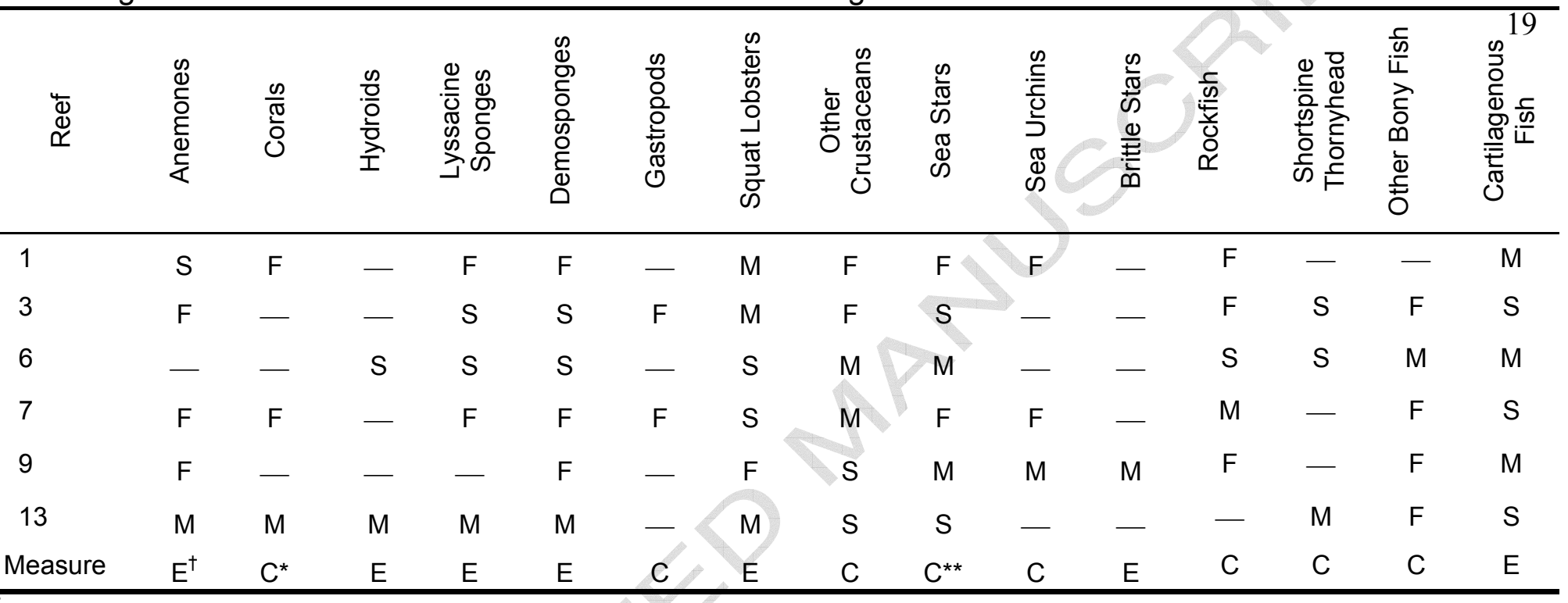

${ }^{\top}$ For all taxa where total number of individuals was estimated $F=<10, S=10-50$ and $M=>50$.

${ }^{*}$ For taxa where individuals were counted (except Sea Stars) $F=<10, S=10-20$ and $M=>20$.

**For Sea Stars $F=<15, S=15-50$ and $M=>50$; this criteria is different from the other taxa that were counted due to the higher general abundance of this taxon. 